\title{
List of Figured
}

\subsection{Guatemala 2}

1.2 The Twenty-one Mayan Languages of Guatemala 5

2.1 Tecpán, Patzún, and the Surrounding Area 32

2.2 The Department of Chimaltenango and Its Municipios 34

2.3 Ethnic Demography of Urban Tecpán and Patzún 35

2.4 Tecpán after the 1976 Earthquake 37

2.5 The Columns in Tecpán's Catholic Church 38

2.6 Brick Stove 41

2.7 Adobe Houses in Patzún 42

2.8 A Traditional Adobe Tuj 43

2.9 Playing Tops in Tecpán 47

2.10 The Tlaxcalans at Iximche' 49

2.11 Map of Land Returned in the Xpantzay Lawsuit 53

2.12 Clandestine Graves in Tecpán 60

3.1 Coffee and Cochineal Exports, 1867-1871 72

3.2 Guatemala's Principal Exports 73

3.3 Guatemala's Principal Imports 74

3.4 Total Official Direct Assistance and U.S. Military Aid to Guatemala 80

3.5 Total Official Direct Assistance 82 
4.1 Chávez's Supplemental Alphabet for Quí-chè Maya 88

4.2 Flyer Produced by the Sociedad Ixim for the 1994 Elections 95

5.1 Kaqchikel Neologisms and Their Sources 121

5.2 Accepted Kaqchikel Neologisms and Their Metaphorical Bases 122

5.3 Cover of COMG's Rujunamil Ri Mayab' Amaq' 126

5.4 "Peoples of Guatemala," a Map Produced by Cholsamaj 129

5.5 "Peoples of Guatemala," a Map Produced by Cholsamaj 130

5.6 "Territory of the Maya People before 1492," a Map Produced by Cholsamaj 132

5.7 Promotional Jingoes from the Mayab' Winäq Radio Program 134

6.1 Cave at Pulchich 156

7.1 Kaqchikel Kinship Terminology, Male Ego 171

7.2 Tecpán Household Compound 173

7.3 Barrios of Tecpán 175

7.4 Cantones of Patzún 177

7.5 Religion and Ethnicity in Tecpán and Patzún 181

7.6 Procession of Saint Francis of Assisi, Tecpán, 1994184

7.7 Cofradía Drum and Flute Players 186

8.1 Vilma I, the Tecpán Military Base's Candidate for Indian Queen in 1994197

8.2 Princesa Ixmukane, the Weaving Cooperative's Candidate for Indian Queen in 1994199

8.3 Kaqchikel Language Proficiency among Indians in Tecpán and Patzún 203

8.4 Patzún Huipil with Embroidered Maya Day Names 212

9.1 Primary Economic Activity of Male Heads of Household in Tecpán and Patzún, 1994218

9.2 Milpa after the Tercer Trabajo 221

9.3 Fields of Nontraditional Crops around Tecpán 234 